\title{
The Determination and Evaluation of the Biological Activities for the Commercialization of Recombinant Follicle-Stimulating Hormone in Vitro
}

\author{
Jianwen Hu, Jizhong Han, Xian Zhang, Fei Chen, Lanlan Liu, Bin Zeng* \\ School of Life Science, Jiangxi Science \& Technology Normal University, Nanchang, China \\ Email: ${ }^{\star} J i a n w e n H u 0806 @ 163 . c o m$
}

How to cite this paper: Hu, J.W., Han, J.Z., Zhang, X., Chen, F., Liu, L.L. and Zeng, B. (2016) The Determination and Evaluation of the Biological Activities for the Commercialization of Recombinant Follicle-Stimulating Hormone in Vitro. Journal of Biosciences and Medicines, 4, 31-36. http://dx.doi.org/10.4236/jbm.2016.412005

Received: October 12, 2016 Accepted: November 24, 2016

Published: December 1, 2016

\begin{abstract}
Follicle-stimulating hormone (FSH) plays a central role in mammals reproduction, with the actions of FSH mediated by follicle-stimulating hormone receptors (FSHRs) on the surface of target cells. The purposes of this study were to determine and evaluate the biological activities for the commercialization of recombinant folliclestimulating hormone ( $\mathrm{rFSH})$ in vitro through the cellular internalization using cloned 293T-FSHR cell lines as target. Using imaging approaches we have found here that a little fluorescent signal from the surface of the cell transferred to the cytoplasm and accumulated around the nucleus by endocytosis. Compared with the control groups, the commercialization of $\mathrm{rFSH}$ have not the significant differences of internalization, but the rFSH have promoted the internalization of the fluorescent, suggested that this detection system might as a protocol for the bioactivity of recombinant therapeutic proteins in vitro.
\end{abstract}

\section{Keywords}

Recombinant Follicle-Stimulating Hormone (rFSH), Follicle-Stimulating Hormone Receptor(FSHR ), Cellular Internalization

\section{Introduction}

G protein-coupled receptors (GPCRs) are a superfamily of cell-surface receptors which modulate a variety of cell functions through coupling to heterotrimeric G-proteins and regulating downstream effectors such as adenylyl cyclases, phospholipases, protein kinases and ion channels [1]. FSHR belongs to the subfamily of GPCRs, which have great 
potential as therapeutic targets for abroad spectrum of diseases [2] [3] [4]. Folliclestimulating hormone (FSH) was an important glycoprotein hormone to regulate reproduction in mammals, it acts through binding to follicle-stimulating hormone receptor (FSHR) on target cell surfaces [5] [6]. The biological activities and half-life of FSH are associated with glycosylation, sialylation and sulfation [7] [8].

As the biotechnology has rapidly expanded in recent years, the majority of recombiant proteins have been produced by the genetic engineering technique using different host cell systems for the expression of heterologous genes such as Escherichia coli, Yeast, Insect/baculovirus, Mammalian cells, as well as Eukaryotic individuals, both of which have inherent advantages and drawbacks [9] [10]. Besides, a variety of proteins analogues have been obtained via chemical synthesis [11] [12] [13].

However, the bioactivity and physicochemical characteristics of the recombiant protein are not clearer in vitro or in vivo. At present, the mainly methods to detect the in vitro bioactivity for the recombinant follicle-stimulating hormone by the rat granulosa cell or the Sertoli cell aromatization bioassays [14] [15] and follicle-stimulating hormone radioreceptor activity methods [16]. In this study, we have adopted a methods of the pSNAPf-ADR $\beta 2$-FSHR [17] and cellular internalization [18] to determination and evaluation for the biological activities of recombinant follicle-stimulating hormone in vitro.

\section{Materials and Methods}

\subsection{Reagents and Standards}

The cloned human kidney 293T-FSHR cell strains (our laboratory), 96-well cell culture plates (NEST), SNAP-Surface ${ }^{\mathrm{Tm}} 549$ (NEB), DMEM (Hyclone), Fetal bovine serum (WISTEN), Bovine serum albumin(BSA, Sigma-Aldrich; USA), Puregon (Organon, Netherlands), Carbon dioxide incubator(Thermo), Fluorescence microscope (Bio-Rad).

\subsection{The Cellular Internalization for rFSH in Vitro Activity Assay}

A HEK-293T cell lines that had been stably transfected with the pSNAPf-ADR $\beta 2$-FSHR was used to detect fluorescent signal in response to the commercialization of recombinant follicle-stimulating hormone ( $\mathrm{rFSH})$ stimulation. Fluorescent signal were determined using imaging approaches, the total process of the cellular internalization as follows.

Cells were cultured in 96-well plates with 200 ul of DMEM supplemented with $10 \%$ fetal bovine serum (FBS). After 48-72 hours, replace the medium with $50 \mathrm{ul} /$ well the labeling medium of $5 \mu \mathrm{M}$ SNAP-Surface 549 (NEB) containing $0.5 \%$ bovine serum albumin (BSA) and incubate at $37^{\circ} \mathrm{C}, 5 \% \mathrm{CO}_{2}$ for 15 minutes. Wash the cells ten times with DMEM (Hyclone) containing 10\% fetal bovine serum (FBS, WISTEN) and PBS (0.01 M, PH7.2), respectively. Adding $50 \mathrm{ul} /$ well Puregon dilution $(30 \mathrm{mIU} / \mathrm{ml})$ and set the controls, respectively. Image the cells using the Fluorescence microscope (Bio-Rad) and continuously recording $0 \mathrm{~min}, 30 \mathrm{~min}, 60 \mathrm{~min}, 90 \mathrm{~min}, 120 \mathrm{~min}, 150 \mathrm{~min}$. 


\section{Results}

The cellular internalization for rFSH in vitro activity assay, we have found here that a little fluorescent signal from the surface of the cell transferred to the cytoplasm and accumulated around the nucleus. Compared with the control groups, the commercialization of rFSH have not the significant differences of internalization. The control groups (Figure 1), after $90 \mathrm{~min}$ appeared a large number of fluorescence accumulated around the nucleus. However, the experimental groups (Figure 2), after 60 min have appeared the fluorescence accumulated around the nucleus. Suggested that the recombinant follicle-stimulating hormone promoted the fluorescent from the surface of the cells into the cytoplasm and accumulated around the nucleus. Meanwhile, the results indicated that this detection system was successed in determination and evaluation of the biological activities for $\mathrm{rFSH}$ in vitro.

$0 \mathrm{~min}$

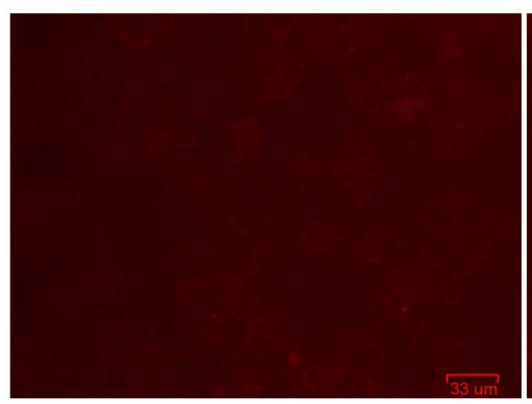

$60 \mathrm{~min}$

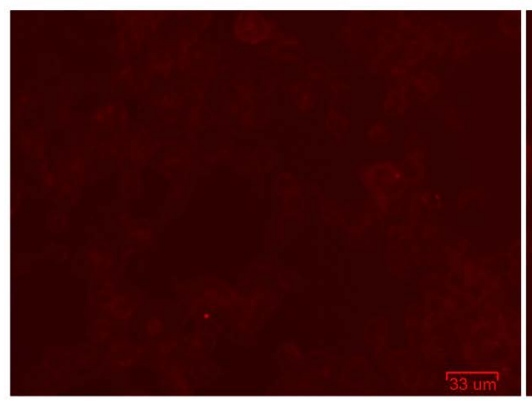

$120 \mathrm{~min}$

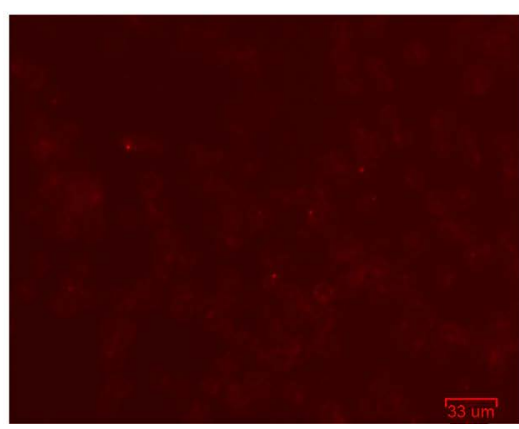

Figure 1. The control goroups: $50 \mathrm{ul} /$ well PBS, images acquisition from $0 \mathrm{~min}$ to $150 \mathrm{~min}$.
$30 \mathrm{~min}$

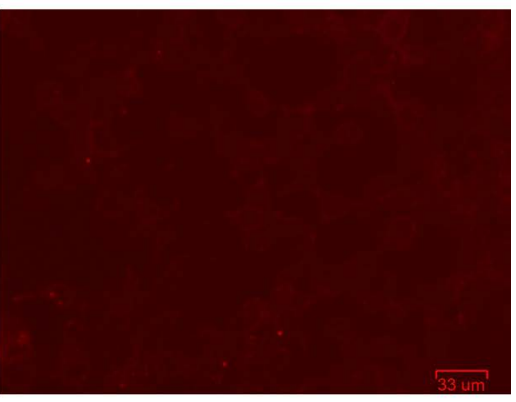

$90 \mathrm{~min}$

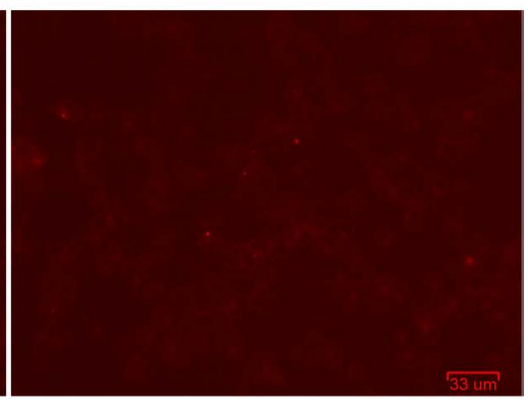

$150 \mathrm{~min}$

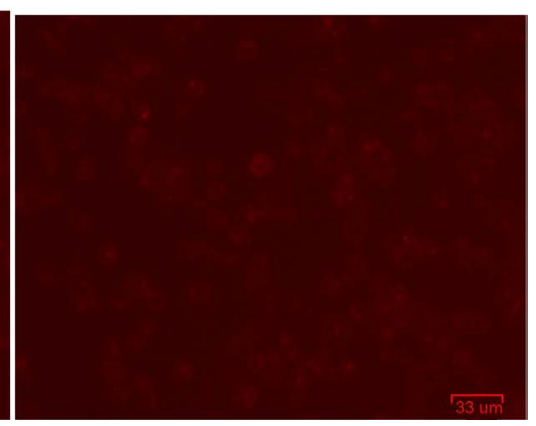



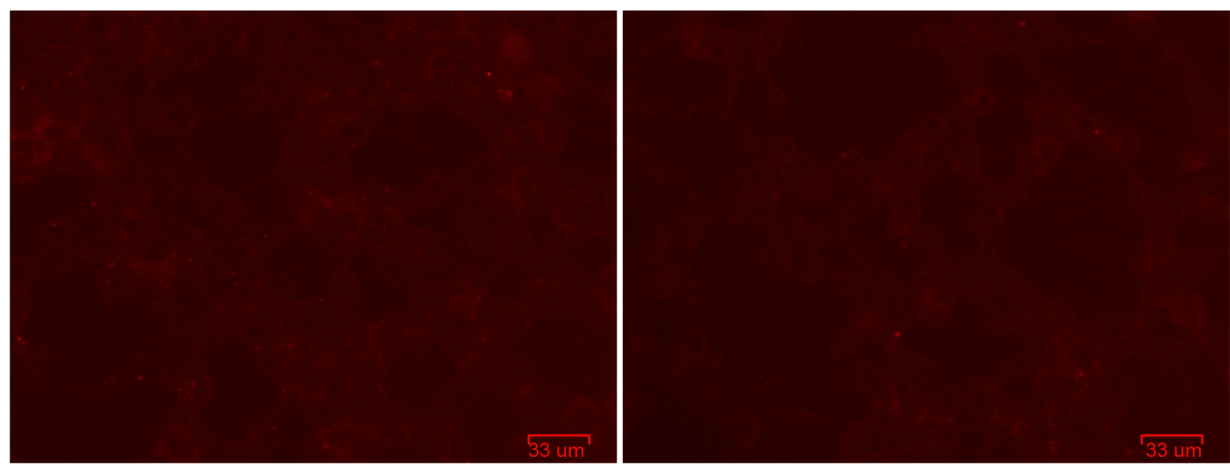

$60 \mathrm{~min}$

$90 \mathrm{~min}$
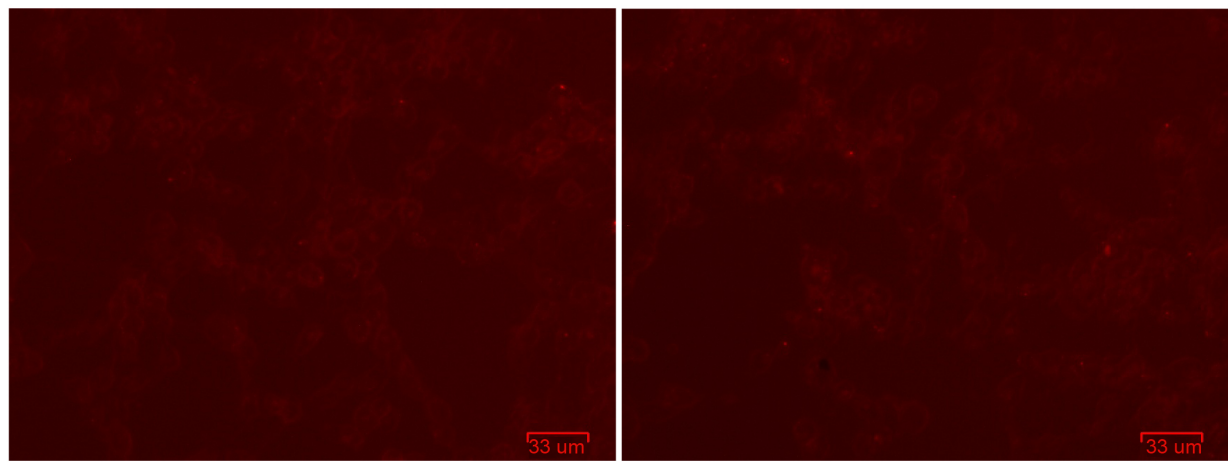

$120 \mathrm{~min}$

$150 \min$
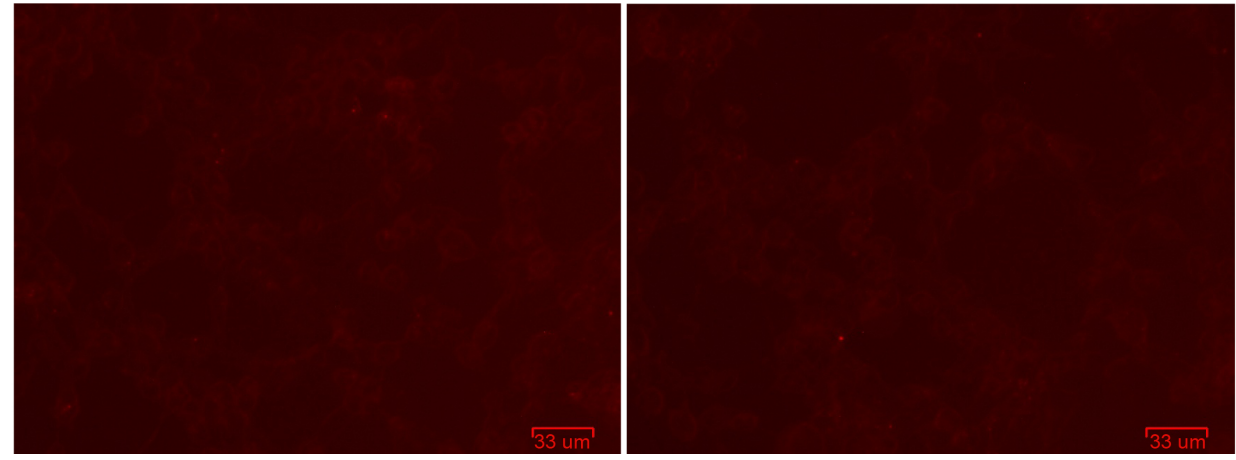

Figure 2. The experimental groups: $50 \mathrm{ul} /$ well pruegon dilution $(30 \mathrm{mIU} / \mathrm{ml})$, images acquisition from $0 \mathrm{~min}$ to $150 \mathrm{~min}$.

\section{Discussion}

The detection system based on the FSH receptor activation by FSH, FSHR induces intracellular cAMP synthesis, in turn, triggers downstream signal transduction [19] [20]. To reduce background interference, used $0.5 \%$ bovine serum albumin (BSA) in the labeling medium and removed the SNAP-Surface 549 dye with DMEM containing $10 \%$ fetal bovine serum (FBS). Compared with the control groups, the commercialization of the rFSH have promoted the internalization of the fluorescence, suggested that this detection system might as a protocol for the bioactivity of recombinant therapeutic 
proteins in vitro.

However, there are also many drawbacks such as low sensitivity, inconvenience in tracing images, and unsatisfied in recognising result. In the next study, we will further improve the detection system of bioactivity for $\mathrm{rFSH}$ and combined with cAMP-Screen cAMP Immunoassay System [21] [22].

\section{Acknowledgements}

This work was supported by these projects in China (31171731, 31460447, 20142BDH80003, 2013-CXTD002, “555 talent project” of Jiangxi Province, Jiangxi Province Key Laboratory of Bioprocess Engineering and Co-Innovation Center for in vitro Diagnostic Reagents and Devices of Jiangxi Province).

\section{References}

[1] Rosenbaum, D.M., Rasmussen, S.G.F. and Kobilka, B.K. (2009) The Structure and Function of G-Protein-Coupled Receptors. Nature, 459, 356-363. http://dx.doi.org/10.1038/nature08144

[2] Lagerström, M.C. and Schiöth, H.B. (2008) Structural Diversity of G Protein-Coupled Receptors and Significance for Drug Discovery. Nature Reviews Drug Discovery, 7, 339-357. http://dx.doi.org/10.1038/nrd2518

[3] Radu, A., Pichon, C., Camparo, P., et al. (2010) Expression of Follicle-Stimulating Hormone Receptor in Tumor Blood Vessels. New England Journal of Medicine, 363, 1621-1630. http://dx.doi.org/10.1056/NEJMoa1001283

[4] Liu, X.M., Chan, H.C., Ding, G.L., et al. (2015) FSH Regulates Fat Accumulation and Redistribution in Aging through the Goi/Ca ${ }^{2+} / \mathrm{CREB}$ Pathway. Aging Cell, 14, 409-420. http://dx.doi.org/10.1111/acel.12331

[5] Fan, Q.R. and Hendrickson, W.A. (2005) Structure of Human Follicle-Stimulating Hormone in Complex with Its Receptor. Nature, 433, 269-277. http://dx.doi.org/10.1038/nature03206

[6] Moyle, W.R., Lin, W., Myers, R.V., et al. (2005) Models of Glycoprotein Hormone Receptor Interaction. Endocrine, 26, 189-205. http://dx.doi.org/10.1385/ENDO:26:3:189

[7] Perlman, S., van den Hazel, B., Christiansen, J., et al. (2003) Glycosylation of an N-Terminal Extension Prolongs the Half-Life and Increases the in Vivo Activity of Follicle Stimulating Hormone. The Journal of Clinical Endocrinology \& Metabolism, 88, 3227-3235. http://dx.doi.org/10.1210/jc.2002-021201

[8] Wide, L., Eriksson, K., Sluss, P.M., et al. (2009) Serum Half-Life of Pituitary Gonadotropins Is Decreased by Sulfonation and Increased by Sialylation in Women. The Journal of Clinical Endocrinology \& Metabolism, 94, 958-964. http://dx.doi.org/10.1210/jc.2008-2070

[9] Verma, R., Boleti, E. and George, A.J.T. (1998) Antibody Engineering: Comparison of Bacterial, Yeast, Insect and Mammalian Expression Systems. Journal of Immunological Methods, 216, 165-181. http://dx.doi.org/10.1016/S0022-1759(98)00077-5

[10] Yin, J., Li, G., Ren, X., et al. (2007) Select What You Need: A Comparative Evaluation of the Advantages and Limitations of Frequently Used Expression Systems for Foreign Genes. Journal of Biotechnology, 127, 335-347. http://dx.doi.org/10.1016/j.jbiotec.2006.07.012

[11] Dawson, P.E. and Kent, S.B.H. (2000) Synthesis of Native Proteins by Chemical Ligation. Annual Review of Biochemistry, 69, 923-960. http://dx.doi.org/10.1146/annurev.biochem.69.1.923 
[12] Kent, S.B.H. (2009) Total Chemical Synthesis of Proteins. Chemical Society Reviews, 38, 338-351. http://dx.doi.org/10.1039/B700141J

[13] Aussedat, B., Fasching, B., Johnston, E., et al. (2012) Total Synthesis of the $\alpha$-Subunit of Human Glycoprotein Hormones: Toward Fully Synthetic Homogeneous Human FollicleStimulating Hormone. Journal of the American Chemical Society, 134, 3532-3541. http://dx.doi.org/10.1021/ja2111459

[14] Van Damme, M.P., Robertson, D.M., Marana, R., et al. (1979) A Sensitive and Specific in Vitro Bioassay Method for the Measurement of Follicle-Stimulating Hormone Activity. Acta Endocrinologica, 91, 224-237. http://dx.doi.org/10.1530/acta.0.0910224

[15] Barrios-De-Tomasi, J., Timossi, C., Merchant, H., et al. (2002) Assessment of the in Vitro and in Vivo Biological Activities of the Human Follicle-Stimulating Isohormones. Molecular and Cellular Endocrinology, 186, 189-198. http://dx.doi.org/10.1016/S0303-7207(01)00657-8

[16] Burgon, P.G., Robertson, D.M., Stanton, P.G., et al. (1993) Immunological Activities of Highly Purified Isoforms of Human FSH Correlate with in Vitro Bioactivities. Journal of Endocrinology, 139, 511-518. http://dx.doi.org/10.1677/joe.0.1390511

[17] Albanese, C., Christin-Maitre, S., Sluss, P.M., et al. (1994) Development of a Bioassay for FSH Using a Recombinant Human FSH Receptor and a cAMP Responsive Luciferase Reporter Gene. Molecular and Cellular Endocrinology, 101, 211-219. http://dx.doi.org/10.1016/0303-7207(94)90237-2

[18] Krishnamurthy, H., Kishi, H., Shi, M., et al. (2003) Postendocytotic Trafficking of the Follicle-Stimulating Hormone (FSH)-FSH Receptor Complex. Molecular Endocrinology, 17, 2162-2176. http://dx.doi.org/10.1210/me.2003-0118

[19] Hunzicker-Dunn, M. and Maizels, E.T. (2006) FSH Signaling Pathways in Immature Granulosa Cells That Regulate Target Gene Expression: Branching out from Protein Kinase A. Cellular Signalling, 18, 1351-1359. http://dx.doi.org/10.1016/j.cellsig.2006.02.011

[20] Wayne, C.M., Fan, H.Y., Cheng, X., et al. (2007) Follicle-Stimulating Hormone Induces Multiple Signaling Cascades: Evidence That Activation of Rous Sarcoma Oncogene, RAS, and the Epidermal Growth Factor Receptor Are Critical for Granulosa Cell Differentiation. Molecular Endocrinology, 21, 1940-1957. http://dx.doi.org/10.1210/me.2007-0020

[21] Casarini, L., Moriondo, V., Marino, M., et al. (2014) FSHR Polymorphism p. N680S Mediates Different Responses to FSH in Vitro. Molecular and Cellular Endocrinology, 393, 8391. http://dx.doi.org/10.1016/j.mce.2014.06.013

[22] Zhang, Y.L., Guo, K.P., Ji, S.Y., et al. (2016) Development and Characterization of a Novel Long-Acting Recombinant Follicle Stimulating Hormone Agonist by Fusing Fc to an FSH- $\beta$ Subunit. Human Reproduction, 31, 169-182. http://dx.doi.org/10.1093/humrep/dev295 
Submit or recommend next manuscript to SCIRP and we will provide best service for you:

Accepting pre-submission inquiries through Email, Facebook, LinkedIn, Twitter, etc. A wide selection of journals (inclusive of 9 subjects, more than 200 journals)

Providing 24-hour high-quality service

User-friendly online submission system

Fair and swift peer-review system

Efficient typesetting and proofreading procedure

Display of the result of downloads and visits, as well as the number of cited articles

Maximum dissemination of your research work

Submit your manuscript at: http://papersubmission.scirp.org/

Or contact jbm@scirp.org 